\title{
APLIKASI RUMAH PINTAR (SMART HOME) PENGENDALI PERALATAN ELEKTRONIK RUMAH TANGGA BERBASIS WEB
}

\author{
Fauzan Masykur ${ }^{1}$, Fiqiana Prasetiyowati ${ }^{2}$ \\ 1,2 Program Studi Teknik Informatika \\ Universitas Muhammadiyah Ponorogo \\ Email: ${ }^{1}$ fauzan.art@gmail.com, ${ }^{2}$ fqkulman24@gmail.com
}

(Naskah masuk: 18 Februari 2016, diterima untuk diterbitkan: 17 Maret 2016)

\begin{abstract}
Abstrak
Teknologi berkembang dengan pesat pada era sekarang, dengan seiring perkembangan teknologi tersebut maka ada dampak yang ditimbulkan. Kontrol peralatan elektronik dapat dilakukan dengan aplikasi rumah pintar (smart home) pengendali peralatan elektronik rumah tangga berbasis web dan dapat di kontrol dengan jarak jauh. Aplikasi rumah pintar (smart home) ini dapat mempermudah pengguna dalam mengontrol peralatan elektronik rumah tangga seperti lampu, AC dan TV sehingga dapat mengurangi adanya pemborosan listrik ketika pengguna lupa untuk mematikan peralatan elektronik rumah tangga ketika keadaan diluar rumah atau dimanapun pengguna berada. Aplikasi ini menggunakan Raspberry Pi yang berfungsi sebagai server yang akan menghubungkn antara hardware dan software yang dikontrol melalui web sebagai interface yang digunakan pengguna untuk memasukan input dan menghasilkan output. Pembuatan web ini menggunakan sistem operasi Rasbian dimana software yang digunakan adalah PHP5. Fitur yang ada pada web ini adalah berupa 6 tombol, dimana 3 tombol berwarna biru sebagai aturan on dan 3 tombol berwarna merah sebagai aturan $o f f$.
\end{abstract}

Kata kunci: Smart Home, Raspberry Pi, PHP5, Web

\begin{abstract}
Technology is developing rapidly in this era, with the concomitant development of these technologies then no impact. Control electronic equipment can be done with smart home applications (smart home) controlling home electronics is web based and can be controlled remotely. Smart home applications (smart home) can facilitate the user in control of household electronic equipment such as lights, air conditioning and TV so as to reduce the wastage of electricity when the user forgets to turn off household electronic equipment when circumstances outside the home or wherever the user is located. This application uses Raspberry Pi that functions as a server that will menghubungkn between hardware and software that is controlled through a web interface for a user to enter input and produce output. Making the web using the operating system software used Rasbian which is PHP5. The existing features of this web is in the form of six buttons, in which three blue button as rules on and 3 red button as a rule off.
\end{abstract}

Keywords: Smart Home, Raspberry Pi, PHP5, Web

\section{PENDAHULUAN}

\subsection{Latar Belakang}

Alat listrik adalah segala peralatan yang pengoperasiannya membutuhkan energi listrik. Pemanfaatan energi listrik saat ini kurang efektif karena banyak peralatan elektronik rumah tangga yang menggunakan energi listrik serta pemakainnya sangat berlebihan. Pemakaian energi listrik yang berlebihan akan menyebabkan kelangkaan listrik.

Teknologi saat ini sudah merambah ke dalam kehidupan manusia, seperti adanya pengembangan aplikasi rumah pintar (smart home) yang dapat memberikan kenyamanan, keamanan dan efesien bagi pengguna. Pengendalian jarak jauh merupakan pengendalian yang sangat dibutuhkan mengingat efisiensi yang diperoleh dari pengendalian jarak jauh. Pengendalian akan dilakukan secara otomatis sesuai dengan pengendalian yang di lakukan oleh pengguna.

A smart home is one that has a highly sophisticated automated system to control multimedia equipment for monitoring and enable the security forces (alarm and alert) associated with the windows and doors, lighting and temperature and many other functions. A smart home appears "intelligent" because of a computer system that can memonitorinbg many aspects of daily life (David Bregman, 2010). Jadi, sebuah rumah pintar muncul karena komputer yang dimanfaatkan untuk memantau ataupun mengontrol aspek kehidupan sehari-hari.

Peralatan elektronik rumah tangga yang akan di kendalikan berupa lampu, AC dan TV. Lampu merupakan alat penerang pada tempat yang 
gelap atau pada malam hari, lampu sangat dibutuhkan oleh masyarakat sehingga sering sekali terjadi kelalaian dalam mengendalikan lampu. Seringkali lampu masih menyala pada siang hari atau tempat yang terang, itu disebabkan karena pengguna lupa untuk mematikannya. Begitu juga dengan $\mathrm{AC}$, alat pendingin ruangan ini seringkali lupa di matikan pada saat pengguna sedang keluar ruangan, serta TV yang merupakan media terkenal yang memiliki fungsi sebagai penerima siaran gambar bergerak beserta suara ini sering lupa dimatikan ketika pengguna keluar ruangan ataupun kelur rumah.

Rumah Pintar (Smart Home) itu sendiri merupakan ide dari pengguna rumah untuk dapat mengatur bagian rumahnya yang terintegrasi ke smartphone atau gadget lainnya. Dengan tujuan untuk meningkatkan kualitas hidup penggunanya dan dapat mengelola rumah dengan baik. Aspek yang sangat penting adalah aspek keamanan yang dibutuhkan oleh penggunanya.

Oleh karena itu, kami membuat APLIKASI

RUMAH PINTAR (SMART HOME) PENGENDALI PERALATAN ELEKTRONIK RUMAH TANGGA BERBASIS WEB dengan alat mikrokontroller sebagai pengendalinya. Hal ini merupakan upaya untuk penghematan listrik serta memudahkan pengguna untuk mengendalikan peralatan elektronik rumah tangga sehingga penggunaannya lebih efektif.

\subsection{Rumusan Masalah}

Rumusan masalah aplikasi rumah pintar ini yaitu :

1. Bagaimana cara membuat aplikasi rumah pintar (smart home) pengendali peralatan elektronik rumah tangga dengan berbasis web?

2. Bagaimana membuat aplikasi rumah pintar (smart home) yang memiliki kemampuan untuk mengendalikan peralatan elektronik rumah tangga dengan menggunakan modul mikrokontroller Raspberry Pi ?

\section{METODOLOGI}

Metodologi yang dilakukan adalah metode penelitian. Metode penelitian dalam pembuatan program ini ada dua metode, yaitu :

1. Metode penelitian studi literature

Penelitian dengan menggunakan media internet dan media cetak. Media internet dapat berupa jurnal, E-Book. Sedangkan media cetak dapat berupa buku-buku materi.

2. Metode penelitian studi Eksperimen

Penelitian dengan menggunakan software dan hardware yang di rancang kinerjanya, lalu dilakukan pengujian terhadap pembuatan aplikasi. Setelah itu dilanjutkan dengan melakukan analisa terhadap aplikasi tersebut, apakah aplikasi sudah sesuai dengan yang diinginkan atau belum. Jika hasil sudah sesuai dengan yang diharapkan maka akan disimpulkan hasil yang didapatkan.

3. Metode penelitian sendiri adalah peraturan atau prosedur yang digunakan oleh seorang programmer untuk melakukan kegiatan secara disiplin. Dalam penelitian setiap orang dipengaruhi oleh tujuan serta profesi dari masing-masing pengguna.

\subsection{Definisi Rumah Pintar (Smart Home)}

Rumah Cerdas (Smart Home) adalah aplikasi gabungan antara teknologi dan pelayanan yang dikhususkan pada lingkungan rumah dengan fungsi tertentu yang bertujuan meningkatkan keamanan, efisiensi dan kenyamanan penghuninya. Sistem rumah pintar (smart home) biasanya terdiri dari perangkat monitoring, perangkat kontrol dan otomatis ada beberapa perangkat yang dapat di akses menggunakan komputer (Tri Fajar Yurmama, 2009).

Rumah Pintar (Smart Home) merupakan sebuah aplikasi yang dirancang dengan berbantuan komputer yang akan memberikan kenyamanan, keamanan dan penghematan energi yang berlangsung secara otomatis sesuai dengan kendali pengguna dan terprogram melalui komputer pada gedung atau tempat tinggal kita. Teknologi yang dirancangan untuk rumah pintar ini bertujuan untuk memudahkan pemilik rumah dalam memantau kondisi peralatan elektronik yang terhubung dari gadget yang dimiliki.

\subsection{Definisi Apache}

Apache adalah sebuah nama web server yang bertanggung jawab pada permintaan dan jawaban HTTP dan logging informasi secara lebih detail. Selain itu, Apache juga merupakan suatu web server yang modular, mengikuti standar protokol HTTP dan sangat disukai.

Apache adalah sebuah web server yang dijalankan pada banyak sistem operasi seperti : Unix, BSD, Linux, Microsoft Windows dan Novell Netware serta Platform lainnya. Dan digunakan untuk melayani dan memfungsikan situs web. Protokol yang digunakan untuk melayani fasilitas web/www ini menggunakan HTTP (Dicky Syaiful Huda, 2014).

\subsection{Definisi Raspberry Pi}

Raspberry $\mathrm{Pi}$ adalah Single Board Computer (SBC) seukuran dengan kartu kredit yang dikembangkan oleh Yayasan Raspberry Pi di Inggris (UK) dengan tujuan untuk membuat adanya 
pelajaran ilmu komputer dasar pada sekolah (Mohammad Faisal Hari Darmawan, 2015).

Dalam aplikasi rumah pintar (smart home) ini Raspberry Pi yang di gunakan adalah Raspberry Pi 2 model B. Jenis dari Raspberry Pi atau yang sering di sebut raspi ini adalah Single-Board Computer yang dirilis pada tahun 2012. Komponen raspi ini adalah cpu 700Mhz ARM1176JZF-S core, 4 slot usb, 1 slot memori sdcard, 1 slot rca, 1 slot audio, 1 slot ethernet, 1 slot micro usb power, 1 slot hdmi, 40 pin GPIO.

\subsection{Definisi HTML}

HTML (Hypertext Markup Language) merupakan kumpulan dari simbol atau tag-tag yang dituliskan dalam sebuah file yang dimaksudkan untuk penampilan halaman pada web browser. Tagtag tadi memberitahu browser bagaimana menampilkan halaman web dengan lengkap pada pengguna (Rio Astamal, 2005).

Ekstensi file HTML adalah .html dan .htm. Dokumen HTML dapat di olah dengan menggunakan editor text Notepad atau dengan program Visual HTML Editor seperti Dreamweaver. Dalam pengkodean HTML harus dengan penggunaan tag. Tag merupakan standar frase tertentu yang digunakan untuk mengatur halaman web. Setiap tag di apit dengan tanda kurung runcing. Tag-tag pada HTML dapat ditulis dengan huruf kecil dan besar.

\section{HASIL DAN PEMBAHASAN}

Aplikasi rumah pintar (smart home) adalah aplikasi yang digunakan untuk mengendalikan peralatan elektronik rumah tangga yang berupa lampu, AC dan TV. Pengendalian ini dapat dijalankan oleh pengguna melalui interface web yang akan terhubung dengan mikrokontroller, mikrokontroller yang digunakan dalam aplikasi ini adalah Raspberry Pi. Pada aplikasi rumah pintar (smart home) ini peralatan elektronik yang dikendalikan akan disimulasikan dengan menggunakan LEDLED. Gambaran dari jalannya rangkaian aplikasi rumah pintar (smart home) ditunjukan pada gambar 1 .

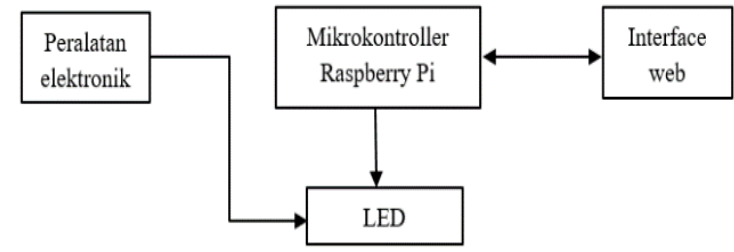

Gambar 1. Rangkaian Aplikasi Rumah Pintar

Pada gambar 1 menjelaskan bahwa peralatan elektronik ini disimulasikan dengan LED. Pengguna mengendalikan peralatan elektronik tersebut dengan interface web yang terhubung dengan mikrokontroller raspberri pi, dari mikrokontroller akan terhubung dengan LED.
Output pada LED sesuai dengan input penguna melalui interface.

\subsection{Flowchart Aplikasi}

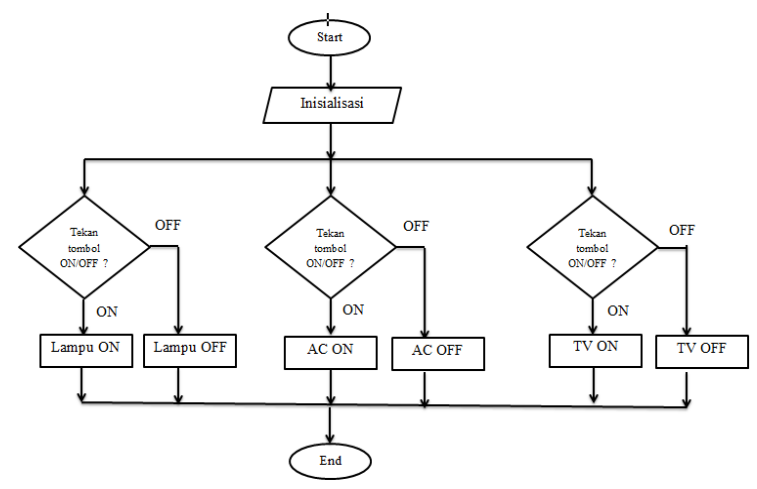

Gambar 2. Flowchart Aplikasi Rumah Pintar

Pada gambar 2 di jelaskan : alur dimuli dari start lalu di lakukan inisialisasi secara manual artinya user memilih inisialisasi perintah terhadap tombol yang ada pada menu. Disini ada 3 tombol, yaitu tombol lampu, tombol AC, dan tombol TV. Selanjutnya user bisa memilih tombol mana yang akan di fungsikan, jika tombol lampu on diklik maka dari web akan mengirimkan perintah ke mikrokontroller lalu akan di lanjutkan ke LED, yaitu LED menyala. Sebaliknya jika yang di klik ada tombol lampu off maka keluarnya adalah LED yang menyala tadi akan mati. Begitu juga dengan tombol yang lainnya, sama prosesnya.

\subsection{Flowchart Login}

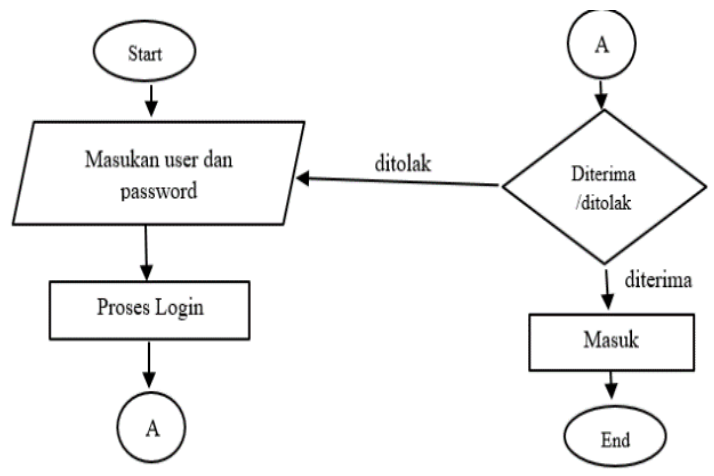

Gambar 3. Flowchart Login

Gambar 3 adalah alur pada saat pengguna akan masuk ke interface. Pertama pengguna masuk ke start lalu melakukan proses input user dan password. Lalu akan di proses, jika diterima maka akan masuk ke dalam interface index. Jika ditolak maka akan kembali ke proses input. 


\subsection{Desain Interface}

Desain interface pada aplikasi rumah pintar (smart home) ini terdiri dari dua bagian, yaitu interface login, interface gpio.

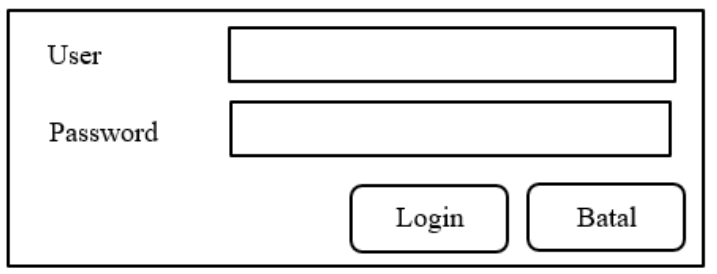

Gambar 4. Interface Login

Halaman pertama pada web adalah interface login. Masukkan user dan password, jika sesuai maka dapat masuk ke interface index.php tapi jika tidak sesuai maka akan tetap pada interface login.

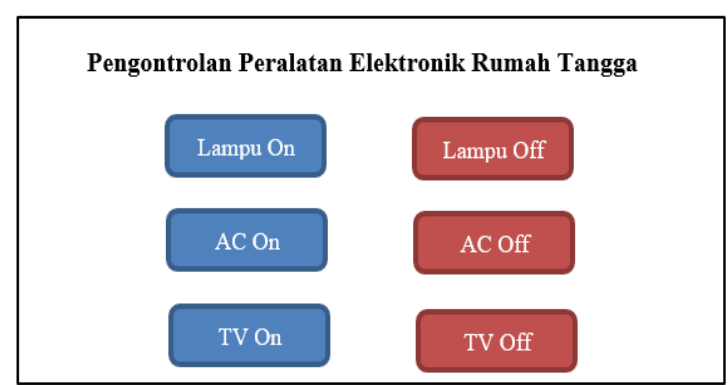

Gambar 5. Interface GPIO

Halaman Kedua pada web adalah interface index.php. Dimana pada halaman ini adalah saklar dari web untuk mengontrol peralatan elektronik rumah tangga yang berupa lampu, AC dan TV yang disimulasikan dengan menggunakan LED. Pada interface index.php ada 6 tombol, 3 tombol untuk kondisi LED on dan 3 tombol untuk kondisi LED off.

\subsection{Merancang Software}

Implementasi dibuat berdasarkan hasil rancangan aplikasi yang telah dibuat sebelumnya. Implementasi yang dibuat mendekati dengan hasil penelitian, sehingga rancangan aplikasi yang telah dibuat tidak keluar dari rancangan kebutuhan aplikasi yang telah dirancang. Aplikasi smart home terdiri dari dua bagian utama, yaitu user interface dan Raspberry Pi sebagai web server sebagai administrator. Dibawah ini adalah penjelasan tentang langkah-langkah pembuatan aplikasi smart home yang telah dibuat.

Pada aplikasi smart home ini menggunakan Raspberry Pi sebagai server yang menggunakan sistem operasi Rasbian yang berbasis dari Linux. Pertama siapkan software yang dibutuhkan, yaitu file Raspbian (NOOB_v1_8_0). Lalu siapkan Micro SD 8gb untuk menyimpan os dan program pada Raspberry Pi. Dan SDFormatter yang digunakan untuk memformat Micro SD, SDFormatter dapat dilihat pada gambar 6 .

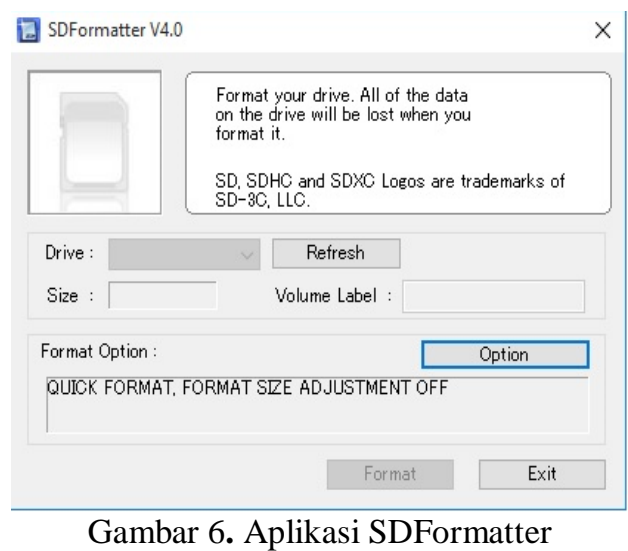

Keterangan gambar 6 adalah :

1. Menu drive arahkan pada drive apa micro sd yang akan di format.

2. Volume label pada micro sd yang diformat.

3. Option adalah pengaturan untuk pemilihan format size on / off.

Klik tombol format untuk format micro sd dan klik exit untuk keluar aplikasi.

Ketika pertama kali Raspberry Pi terhubung dengan komputer maka akan muncul tampilan seperti gambar 7. Pilih menu checkbox yang ada pada tampilan tersebut, lalu tekan enter.

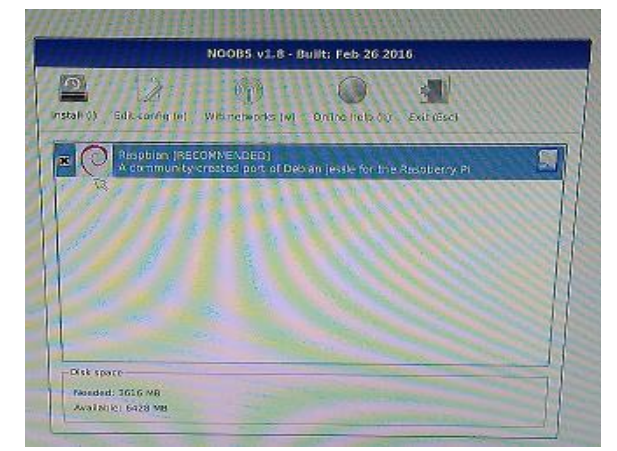

Gambar 7. Tampilan Installasi Sistem Operasi

Installasi ini dimulai dari $0 \%$ menuju ke $100 \%$. Jika installasi sudah selesai maka sistem operasi Rasbian telah terpasang dan siap untuk di install software yang diperlukan berikutnya.

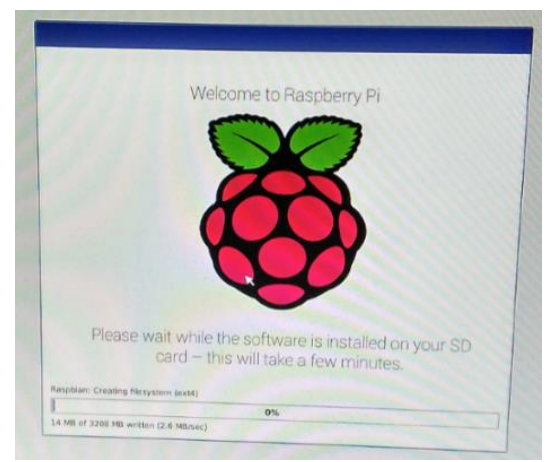

Gambar 8. Interface Installasi Sistem Operasi 


\subsection{Penginstallan WiringPi}

Raspberry Pi mempunyai GPIO yang berfungsi sebagai input dan output terhadap objek lain, untuk membuat input dan output yang digunakan sebagai saklar on/off pada simulasi objek yang akan dikontrol penulis menggunakan WiringPi. WiringPi berfungsi untuk membaca datasheet pada Raspberry Pi. Cara untuk menginstall WiringPi, langkah pertama dapat dilihat pada gambar 9.

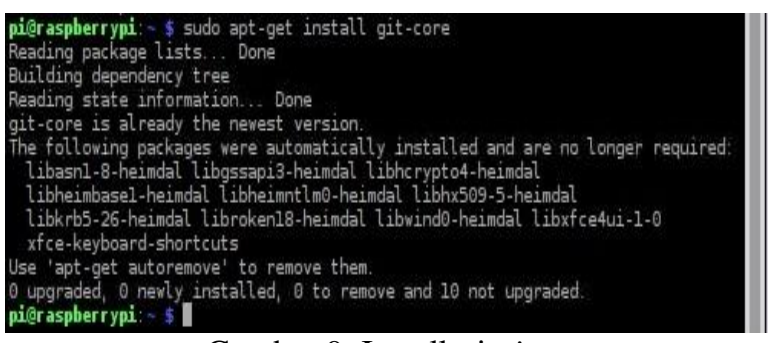

Gambar 9. Installasi git-core

WiringPi merupakan Library open source yang ada dalam project drogon. Untuk mengunduh file tersedia di git. Pertama kali yang di install adalah git-core, setelah git-core selesai di install. Langkah selanjutnya adalah mengunduh WiringPi dengan git clone.

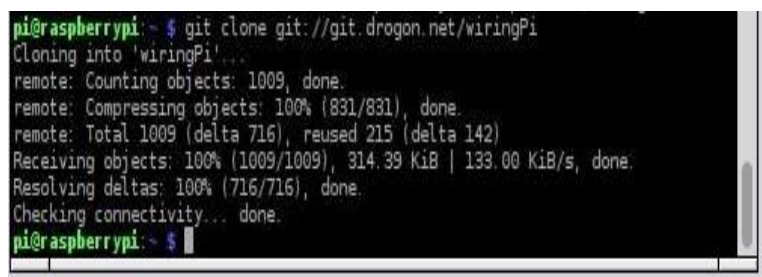

Gambar 10. Clone

Setelah proses cloning telah selesai, file yang sudah diekstrak belum bisa digunakan. Langkah selanjutnya adalah melakukan build.

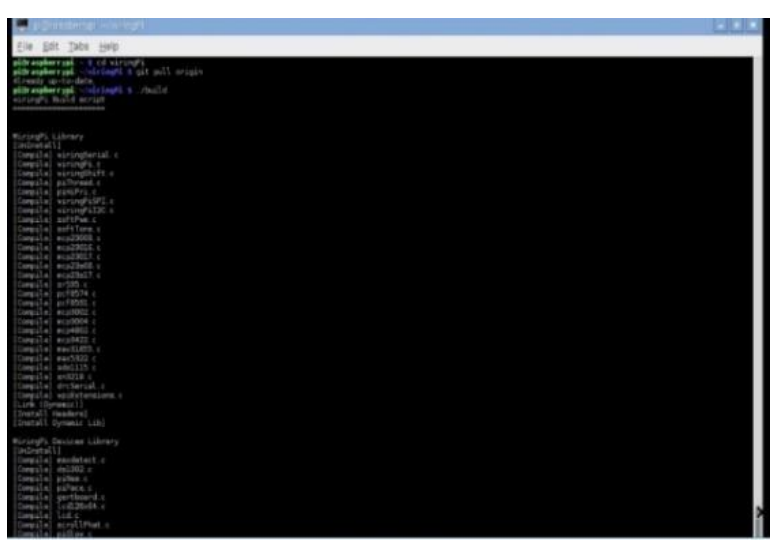

Gambar 11. Build

Akan muncul bebrapa command dari WiringPi setelah WiringPi berhasil di build. Setelah itu WiringPi sudah selesai dan bisa digunakan.

\subsection{Penginstallan PHP5 dan APACHE2}

Perancangan interface yang digunakan pada aplikasi smart home ini adalah PHP5. Cara installasi dapat dilihat pada gambar 12.

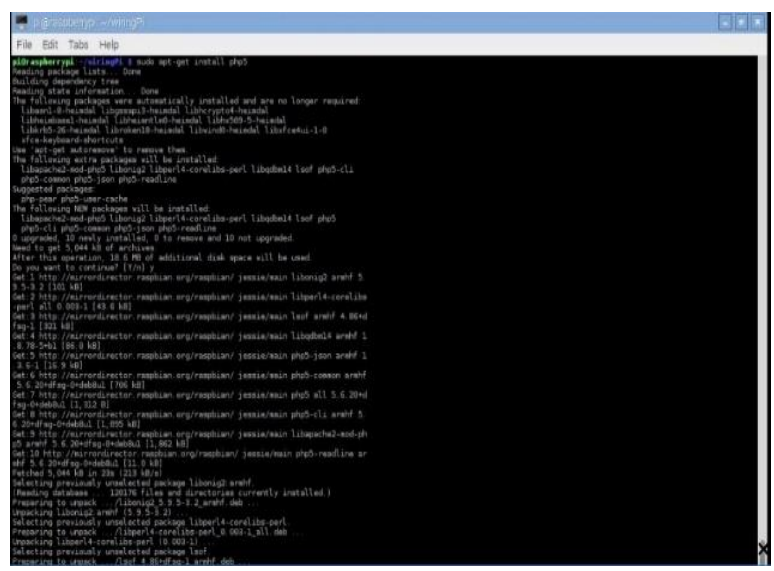

Gambar 12. Installasi PHP5

Setelah PHP5 telah selesai di install dan penginstallan berhasil maka PHP5 dapat digunakan untuk perancangan interface yang menghubungkan antara pengguna dengan GPIO yang tertuju pada library WiringPi.

Apache2 digunakan sebagai web server yang menghubungkan antara pengguna dengan interface web. Cara menginstall apache2 dapat dilihat pada gambar 13 .

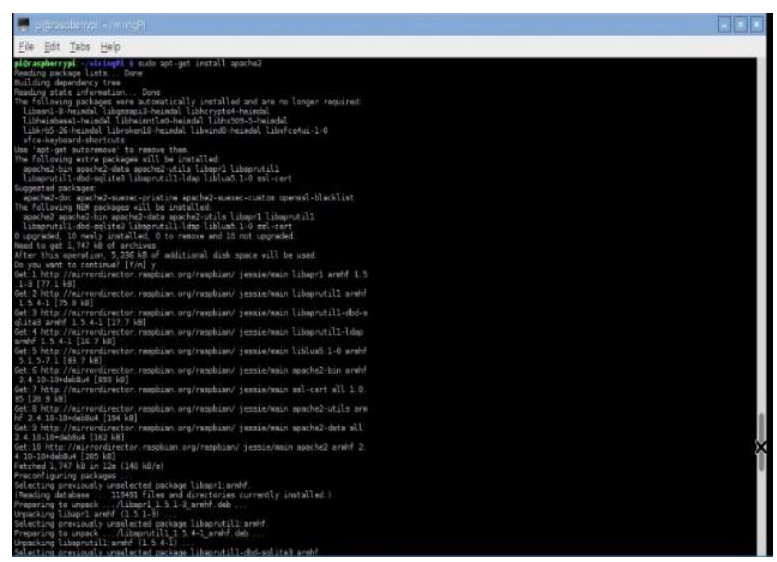

Gambar 13. Installasi Apache5

Setelah apache2 berhasil di install selanjutnya apache2 dapat diaktifkan dengan command "sudo apache2 start". Selanjutnya apache2 sudah aktif dan dpat digunakan sebagai web server.

\subsection{Pengaturan Remote Pada TightVNC}

Tightvnc ini berperan sebagai remote Raspberry Pi agar mendapatkan tampilan Raspberry Pi tanpa menggunakan kyeboard,mouse, monitor dan hdmi converter untuk Raspberry Pi. Cara 
menginstall tightvnc adalah dengan langkah-langkah sebagai berikut :

1. "Sudo apt-get install tightvncserver " tunggu hingga proses done.

2. Langkah selanjutnya " Vncserver " lalu masukkan password untuk vnc.

3. Membuat service tightvncserver otomatis pada saat booting. Potongan kode dapat dilihat pada gambar 14 .

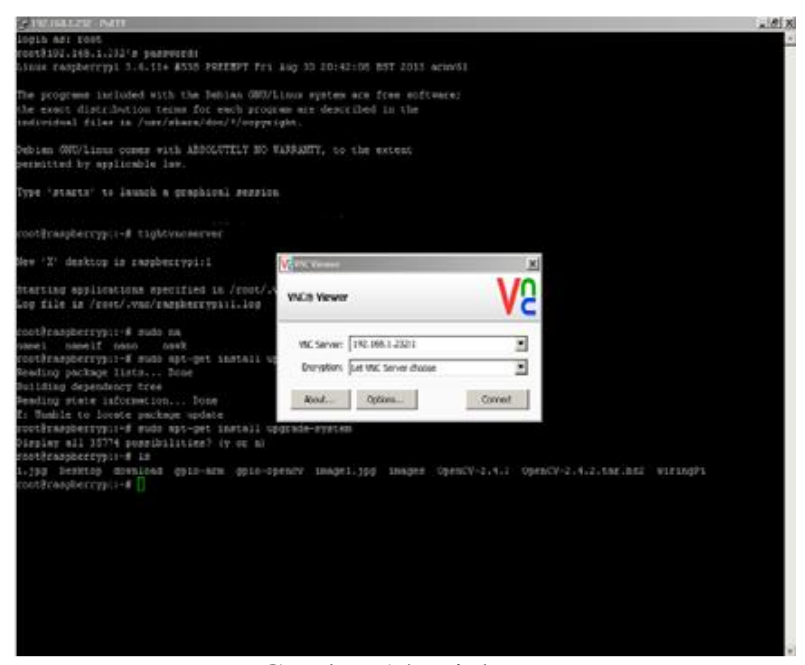

Gambar 14. Tightvncserver

4. lalu lakukan chmod dan reboot

Setelah proses installasi selesai selanjutnya download viewer client untuk windows http://www.tigtvnc.com/download.php. Setelah selesai buka menu TightVNC Viewer yng ada pada komputer atau laptop.

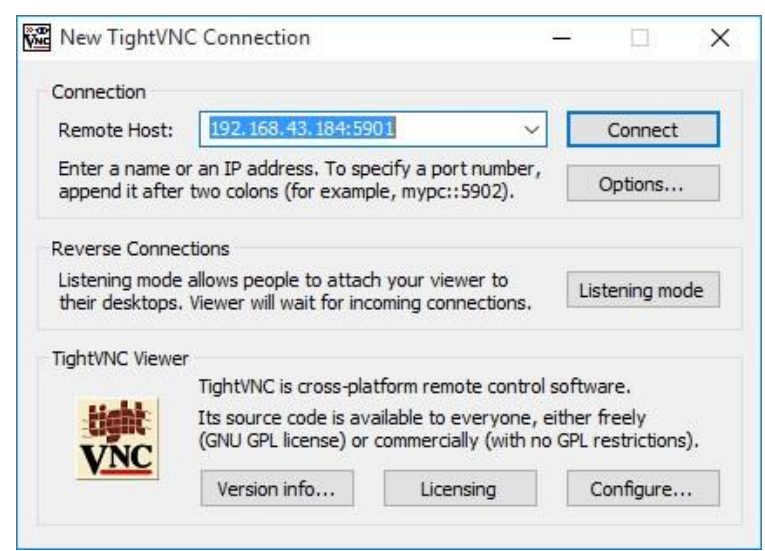

Gambar 15. Tampilan TightVnc Viewer

Gambar 15 adalah tampilan utama tightvnc viewer. Masukkan ip yang terhubung denga Raspberry Pi diikuti dengan port vnc lalu tekan connect. Jika berhasil maka akan muncul tampilan seperti pada gambar 15 .

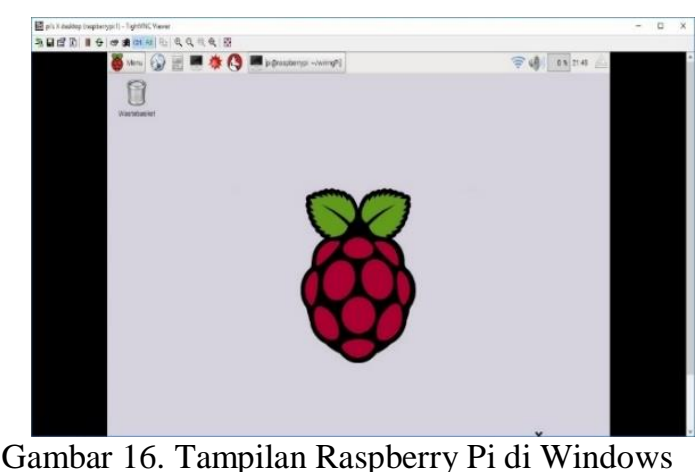

\subsection{Interface Kontrol Smart Home}

Aplikasi smart home pengendali peralatan elektronik rumah tangga ini menggunakan interface berbasis web. Dengan software yang digunakan adalah PHP5, interface digunakan sebagai penghubung antara pengguna dengan GPIO sebagai pengontrol LED.

Didalam file index.php digunakan untuk membuat template atau halaman pada web yang berupa tombol sebagai saklar untuk simulasi LED, dan juga digunakan untuk membaca GPIO yang menghubungkan antara pengguna dengan LED yang tertuju pada library WiringPi.

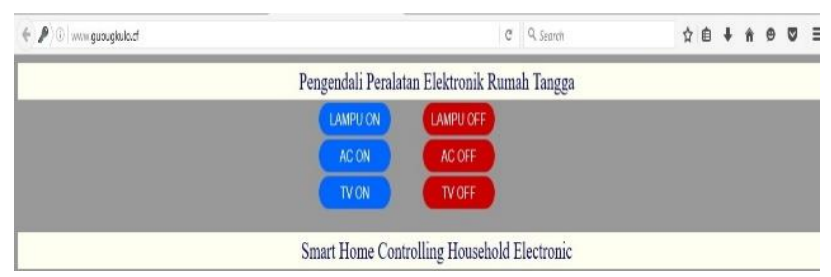

Gambar 17. Interface web

Didalam file index.php digunakan untuk membuat template atau halaman pada web yang berupa tombol sebagai saklar untuk simulasi LED, dan juga digunakan untuk membaca GPIO yang menghubungkan antara pengguna dengan LED yang tertuju pada library WiringPi.

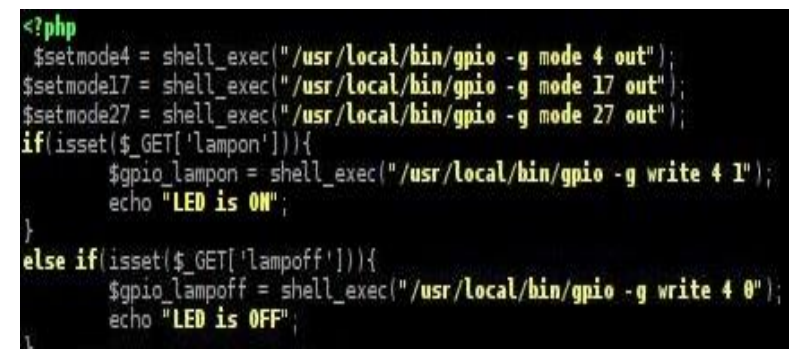

Gambar 17. Potongan Script Index.php

Penjelasan dari gambar 17 adalah menghubungkan antara interface dengan GPIO yang berguna sebagai input maupun sebagai output. Pada script diatas ada 3 LED yang akan di kontrol yaitu LED dengan GPIO 4, 17 dan 27. Jika tombol pada interface yang di tekan adalah tombol dengan nama lampu on yang terletak pada GPIO 4 maka LED yang terhubung dengan 
GPIO 4 akan menyala, dan seterusnya akan seperti itu sesuai dengan tombol yang ditekan yang terhubung pada masing-masing GPIO.

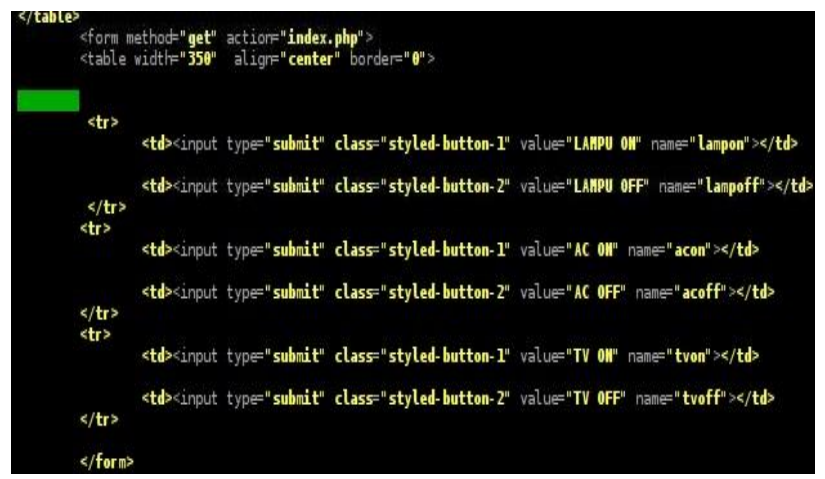

Gambar 18. Potongan Script Index.php

Pada potongan script diatas adalah pembuatan template yang berisi tombol. Pada interface ada 6 tombol yang digunakan. Masingmasing tombol akan terhubung ke script gambar 18 .

\subsection{Pembuatan Login}

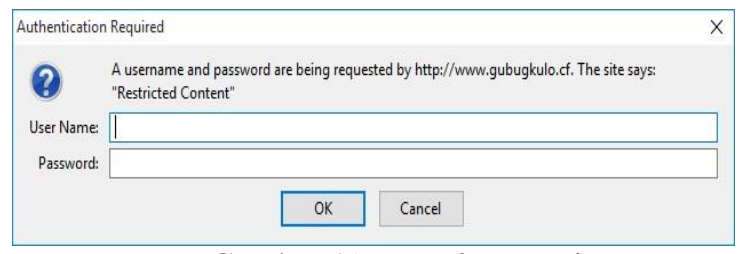

Gambar 19. Interface Login

Login pada aplikasi ini adalah dengan menggunakan Htpasswd tanpa menggunakan database. Htpasswd berfungsi untuk membuat dan memperbarui data file yang digunakan untuk menyimpan user dan password untuk otentikasi dasar pengguna HTTP. Jika htpasswd tidak dapat mengakses file, seperti tidak bisa menulis ke file output atau tidak mampu membaca file untuk memperbaruinya, ia mengembalikan status kesalahan dan membuat tidak ada perubahan.

Langkah awal yang perlu dilakukan adalah menambahkan opsi -c untuk membuat file yang ditentukan. " " sudo htpasswd -c /etc/apache2/.htpasswd admin " pada script ini saya membuat username dengan nama admin. Selanjutnya anda akan diminta untuk menyediakan dan mengkonfirmasi password untuk user.

Setelah langkah diatas selesai, sekarang anda telah memiliki file dengan user dan password dalam format yang apache dapat membaca. Anda juga perlu mengkonfirgurasi apache untuk memeriksa file ini sebelum melayani konten yang dilindungi. Ada dua opsi untuk konfigurasi. Pertama dengan mengedit konfigurasi apache dan menambahkan proteksi password untuk file virtual host. Jika anda tidak memiliki kemampuan untuk memodifikasi file virtual host maka anda dapat membatasi akses dengan menggunakan an.htaccessfile. file apache ini untuk memungkinkan item konfigurasi tertentu yang akan diatur dalam sebuah file di direktori konten.

\section{KESIMPULAN}

Berdasarkan pembahasan yang sudah dijelaskan sebelumnya maka kesimpulan yang dapat diambil sebagai berikut :

1. Telah berhasil membuat Perancangan smart home dengan menggunakan Raspberry Pi berbasis web.

2. Perancangan aplikasi rumah pintar (smart home) dibuat dengan menggunakan Raspberry Pi, rangkaian LED dan dongle.

3. Saklar lampu pada aplikasi rumah pintar (smart home) dikontrol dengan menggunakan interface web yang sudah terhubung ke GPIO.

4. Raspberry Pi digunakan sebagai server yang menghubungkan antara hardware dan software yang dapat digunakan oleh user.

\section{DAFTAR PUSTAKA}

DAO, S. D. \& MARIAN, R. 2011. Optimisation of precedence-constrained production sequencing and scheduling using genetic algorithms. Proceedings of the International Multi Conference of Engineers and Computer Scientists, 16-18 March, Hong Kong.

ASTAMAL, RIO. 2005. "Mastering Kode HTML", (Online). Diakses 04 Mei 2016.

BASKORO, TRI, IMAM. Desember 2014. "Perancangan Pengontrolan Nyala Lampu dan Kipas Angin Pada Sebuah Ruangan Menggunakan Raspberry Pi Model B Dengan Web GUI", (Online), Vol. 3. Diakses 05 Agustus 2016.

BREGMAN, DAVID. Oktober 2010. "Smart Home Intelligence - The eHome that Learns", (Online), Vol. 4. Diakses 05 Agustus 2016.

DARMAWAN, HARI, FAISAL, MOHAMMAD. 2015. "Rancang Bangun Home Automation Berbasis Web Menggunakan Raspberry Pi”, (Online).

HUDA, SYAIFUL, DICKY. Juli 2014. "Prototype Smart Classroom Berbasis Mikrokontroller Menggunakan Raspberry Pi dan Arduino", (Online). Diakses 18 Maret 2016.

OKTAVIANI, WURI, THERESIA. Maret 2014. "Perancangan User Interface Berbasis Web Untuk Home Automation Gateway Yang Berbasis IQRF TR53B", (Online).

PRASAD, SANJANA. 2014. "Smart Surveillance Monitoring System Using Raspberry PI and PIR Sensor", (Online), Vol. 5(6). Diakses 05 Agustus 2016. 
58 Jurnal Teknologi Informasi dan Ilmu Komputer (JTIIK), Vol. 3, No. 1, Maret 2016, hlm. 51-58

RAHAYU, MAYA. 28 Maret 2014. "Pengontrolan Alat Elektronika Melalui Media Wifi Berbasis Raspberry Pi”, (Online), Vol 13. Diakses 02 Februari 2015.

SOLICHIN, ACHMAD. 2009. "Pemograman Web dengan PHP dan MySql", (Online). Diakses 22 April 2014.

YURMAMA, FAJAR, TRI. 20 Juni 2009. "Perancangan Software Aplikasi Pervasive Smart Home", (Online), (http://journal.uii.ac.id/index.php/Snati/arti cle/view/1239/1039. Diakses 28 Desember 2015). 